\title{
Kadınların Meme Kanseri Bilgisinin Beslenme Durumu ve Yaşam Biçimlerine Olan Etkisinin Risk Analizi ile İncelenmesi
}

\author{
Determining the Effect of Breast Cancer Knowledge on Nutritional Status and Lifestyle by Risk \\ Analysis
}

\author{
Rüksan Çehreli ${ }^{1}$ Ayla Açıkgöz², Hülya Ellidokuz ${ }^{1}$
}

Geliş tarihi/Received: 01.12.2019 • Kabul tarihi/Accepted: 30.12.2019

\section{ÖZET}

Amaç: Dünyada ve ülkemizde kadınlarda görülen meme kanseri insidansı son yıllarda hızla artmaktadır. Özellikle artan obezite ve sedanter yaşam şekli bu konuda en önemli risk faktörü olarak görülmektedir. Çalışmanın amacı, hastanede çalışan kadınların meme kanseri konusundaki bilgi ve davranışlarının, beslenme durumları ve yaşam biçimlerine olan etkisinin risk analizi ile değerlendirilmesidir.

Bireyler ve Yöntem: Araştırmada, Dokuz Eylül Üniversitesi Hastanesi’nde destek hizmetlerinde çalışan, 160 kadın (20 yaş ve üzeri) çalışma kapsamına alınmış ve çalışma 155 kişi ile tamamlanmıştır. Kesitsel tipteki bu araştırmada, kadınların meme kanseri risk faktörleri, erken tanı ve tarama yöntemleri hakkındaki bilgi ve davranışları ile birlikte beslenme bilgi ve alışkanlıklarını ölçen bir anket formu uygulanmıştır. Ayrıca katılımcıların antropometrik ölçümleri ve vücut kompozisyonu ölçümleri biyoelektrik impedans analizi (BİA) ile alınmıştır. Kadınların meme kanseri risk analizi Cuzick Tyrer modeline göre değerlendirilmiştir.

Bulgular: Araştırmaya katılan 155 kadının \%81.4'ünün, meme kanseri erken tanı ve tarama yöntemleri konusunda yeterli bilgiye sahip olduğu bulunmuştur. Kadınlar arasında erken tarama yöntemlerinden en sık başvurulan yöntemin 'kendi kendine muayene’ yöntemi olduğu (\%47.7), bunu sırasıyla klinik meme muayenesi (\%30.3) ve mamografinin (\%31.0) takip ettiği saptanmıştır. Bununla birlikte katılımcıların çoğunun (\%60.2) bu yöntemlerden hiçbirini uygulamadığı görülmüştür. Kadınların \%63.9'unda beden kütle indeksinin (BKİ) $25 \mathrm{~kg} / \mathrm{m} 2<$ olduğu ve BKİ> $25 \mathrm{~kg} / \mathrm{m}^{2}$ olan kadınlarda vücut yağ yüzdesinin \%39.06 7.29 olduğu bulunmuştur. Kadınların \%67.1’inin egzersiz yapma alışkanlığının olmadığı saptanmıştır. Cuzick-Tyrer modeline göre yaşam boyu meme kanseri riski yüksek olanların sıklığı \%34.2 olarak bulunmuştur. Her gün zeytinyağı ve meyve sebze tüketenlerin sıklığı sırasıyla \%98.7 ve \%95.5 olarak saptanmıştır.

Sonuç: Kadınların çoğu meme kanserinde erken tanı ve tarama yöntemlerinin önemi konusunda bilgi sahibi olsa da, davranışa yansıtmada halen yetersizlik olduğu görülmektedir. Yaşam boyu tarama testlerinin uygulanması, obezitenin önlenmesi, fiziksel aktivitenin artırılması, riski azaltan besinlerin seçimi, sigara ve alkol gibi risk faktörlerinin azaltılması temel önlemlerdir.

Anahtar kelimeler: Meme kanseri, beslenme, yaşam biçimi, risk analizi

1. İletişim/Correspondence: Dokuz Eylül Üniversitesi Onkoloji Enstitüsü Prevantif Onkoloji Anabilim Dalı, İzmir, Türkiye

E-posta: ruksan.cehreli@deu.edu.tr • $\odot$ https://orcid.org/0000-0002-7714-5385
2. Dokuz Eylül Üniversitesi Tip Fakültesi Halk Sağlığı Anabilim Dalı, İzmir, Türkiye 단 htps://orcid.org/0000-0001-7749-705X

3. Dokuz Eylül Üniversitesi Onkoloji Enstitüsü Prevantif Onkoloji Anabilim Dalı, İzmir, Türkiye • 은ttps://orcid.org/0000-0001-8503-061X 


\section{ABSTRACT}

Aim: In recent years, the incidence of breast cancer among women is increasing rapidly. The increase in obesity prevalence and sedentary lifestyle are the reported major risk factors. The aim of the study was to evaluate the knowledge and behaviors of women working in hospital about breast cancer and effects on nutritional status and lifestyles by risk analysis.

Subjects and Method: Total of 160 women (20 years and older) working in the support services at the Dokuz Eylül University Hospital were included in the study and study was completed on 155 women. In this cross-sectional study, the knowledge and attitudes about the risk factors of breast cancer, methods of early detection and screening, as well as nutritional knowledge and dietary habits were determined by a questionnaire.Anthropometric measurements were taken and body composition was measured by bioelectrical impedance analysis (BIA).Breast cancer risk analysis of women was evaluated according to Cuzick Tyrer model.

Results: It was found that $81.4 \%$ ot the women had sufficient knowledge about early detection and screening methods of breast cancer. 'Breast self-examination' (47.7\%) was the most common screening method among women, followed by clinic breast examination (30.3\%) and mammography (31.0\%). However, most of the participants (60.2\%) did not apply to any of these methods. Body mass index (BMI) was higher than $25 \mathrm{~kg} / \mathrm{m}^{2}$ in $63.9 \%$ of the women and mean body fat percentage was $39.06 \% \pm 7.29$ in women with a BMI $>25 \mathrm{~kg} / \mathrm{m}^{2}$. However, $67.1 \%$ did not have a regular exercise habit. According to CuzickTyrer model, the lifetime breast cancer risk was $34.2 \%$. The frequency of daily olive oil and vegetable-fruit consumption was $98.7 \%$ and $95.5 \%$, respectively.

Conclusion: Although the majority of women are aware of the importance of early detection and screening methods in breast cancer, implementation of these methods is still lacking. Application of lifelong screening tests, obesity prevention, increasing physical activity, selection of foods that reduce risk, reducing risk factors such as smoking and alcohol are the basic measures.

Keywords: Breast cancer, nutrition, lifestyle, risk analysis

\section{GİRIŞ}

Meme kanseri, dünyada ve Türkiye'de kadınlarda en sık görülen kanser tipi ve kanserden ölümlerin ikinci nedenidir (1,2). Meme kanseri erken teşhis edildiğinde oldukça başarılı tedavi sonuçları elde edilebilen ve ölüm oranı azaltılabilen bir kanser tipidir. Bazı basit erken tanı ve tarama yöntemleri kullanılarak kısa sürede tanısı konulabilmekte ve erken dönemde tedaviye başlanabilmektedir (3). $\mathrm{Bu}$ yöntemler arasında en sık başvurulan tarama yöntemleri; kendi kendine meme muayenesi (KKMM), klinik meme muayenesi (KMM) ve mamografidir (3,4). Gelişmiş ülkelerde bu yöntemler, kadınlar arasında meme kanseri farkındalığının artırılmasında da yararlı olmakla birlikte, erken tanı ve etkin tedavi ile sağkalımın artmasını da sağlamaktadır $(1,4)$. Tarama programlarının yetersiz olduğu ülkelerde sağlık personeli tarafindan 20 yaş üzeri tüm kadınlara eğitim verilmesi ve kadınların her ay düzenli olarak
KKMM yapması önerilmektedir. Nitekim memede kitlelerin yaklaşık \%80'inin ilk olarak kadınların kendisi tarafından saptandığı bildirilmiştir $(4,5)$.

Etkili önleme ve tarama ancak belirli bir hastada kanser için kesin risk tahmini varsa mümkündür. Epidemiyolojik çalışmalara dayanılarak meme kanseri riskini tahmin etmeye yönelik matematik modeller geliştirilmiştir (5). Hastanın geçmişine yönelik veriler, demografik ve kalıtsal etkenler analiz edilerek meme kanseri için yüksek risk altında olan kadınlar tanımlanabilmektedir. Meme kanseri kemoprevansiyon çalışmaları için hastaları seçici olarak tanımlamak amacıyla, Cuzick-Tyrer modeli ileri düzeydedir ve Uluslararası Meme Önleme Çalışması (IBIS-1) için geliştirilmiştir (5). Meme kanseri gelişme olasılığını artırabilecek cinsiyet, yaşlanma, östrojen, aile öyküsü, gen mutasyonları, 
obezite ve sağlıksız yaşam tarzı gibi sayısız risk faktörü vardır. Postmenopozal ve östrojen reseptörü pozitif vakalarda belirgin bir artış vardır. Dünya Kanser Araştırma Fonu (WCRF) ve Amerikan Kanser Araştırma Derneği (AACR) gibi kuruluşlar, kanserin önlenmesi için ideal vücut ağırlığının korunmasını, haftada en az 150 dakika orta yoğunlukta egzersiz yapılmasını, alkol tüketiminin sınırlandırılmasını ve bitkisel ağırlıklı bir diyet tüketilmesini önermektedir. Yaşam boyu vücut ağırlığının kontrolü ise menopoz sonrası meme kanseri görülmesini önleyebilmektedir (6).

Türkiye'de meme kanseri görülme sıklığı bölgeler arasında farklılık göstermektedir. Meme kanseri insidansı Doğu bölgelere göre Batı bölgelerinde daha yüksektir (7). Sağlık hizmetlerine erişimin daha fazla olmasının bu duruma etkisinin olduğu düşünülmektedir. Sağlık Bakanlığı Türkiye Halk Sağlığı Kurumu Kanser Taramaları Ulusal Meme Kanseri Kayıt Programı verilerine göre meme kanseri olgularının yaklaşık üçte ikisi 40 yaşın altındadır $(7,8)$.

Ülkemizde de artan obezite oranları, fiziksel aktivite eksikliği, alkol tüketimi meme kanseri için yaşam tarzı ile ilgili başlıca risk faktörleridir. Bireysel düzeyde bulgular, vücut ağırlığının azaltılması ve basit davranış değişikliklerinin bile kalıtsal meme kanserinden korunmada önemli bir rolü olabileceğini göstermektedir $(6,9)$. Son ylllarda, meme kanserinin kemoprevansiyonunda ilaç kullanımının yerine yaşam kalitesini iyileştirmek hedeflenmiştir. Özellikle 20 yaş üzeri erişkin döneme geçişte ve menopozda kadınlar için dengeli bir kilo kontrolü ve fiziksel aktivitenin artırılması ile insulin direncinin azaltılması önerilmektedir (9).

$\mathrm{Bu}$ çalışmada hastanede çalışan kadınların, meme kanseri konusundaki bilgisini ve tanı yöntemlerine ilişkin davranışlarını belirleyerek, bu farkındalığın beslenme alışkanlıkları, genel vücut analizleri ve yaşam biçimlerine olan etkisinin meme kanseri risk düzeyleri ile olan ilişkisinin değerlendirilmesi amaçlanmaktadır.

\section{BİREYLER VE YÖNTEM}

\section{Araştırma Yeri ve Örneklemi}

Bu kesitsel araştırma Dokuz Eylül Üniversitesi Onkoloji Enstitüsü’nde (DEÜ) yapılmıştır. Çalışma kapsamına hastanenin destek hizmetlerinde çalışan yaşı 20 ve üzerinde olan 160 kadının dahil edilmesi planlanmış ancak beş kadın kişisel özelliklerinden (gebe kalması, kalp pili veya platin protezi takılması gibi nedenlerle vücut analiz ölçümlerinin alınamayacak olması) dolayı örneklemden çıkarılmıştır. Araştırma için Dokuz Eylül Tıp Fakültesi Girişimsel (İnvaziv) Olmayan Araştırmalar Etik Kurulu'ndan (2009/203) onay alınmıştır. Araştırma öncesi katılmaya gönüllü olan tüm katılımcılara araştırma hakkında bilgi verilmiş ve onam formları okutulup imzalatılmıştır.

\section{Veri Toplama}

Araştırmacılar tarafından hazırlanan anket formları kadınlar ile yüz yüze görüşülerek bilgiler toplanmıştır. Anket formu kadınların sosyaldemografik özellikleri, meme kanserinin erken tanı ve tarama yöntemleri (KKMM, KMM, meme ultrasonu ve mamografi) hakkındaki bilgileri ile bu yöntemleri uygulama davranışlarına yönelik soruları içermektedir. Anket formunda yine kadınların sağlık durumu, kanser hastalığı için risk oluşturabilecek yaşam biçimi davranışlarına (beslenme, besin tüketim sıklığı, fiziksel aktivite) yönelik sorular da yer almıştır. Kadınların yaşam boyu meme kanseri riskini saptamak için Cuzick-Tyrer Modeli kullanılmıştır. Bu modelde riskin belirlenmesi için kalıtsal etkenler, beden kütle indeksi (BKI), menopoz durumu ve hormon replasman tedavisi kullanımı, ilk adet yaşı, ilk hamilelik yaşı değerlendirilmiştir (5).

İlk görüşme sonrası farklı bir günde katılımcılardan antropometrik ve vücut kompozisyonu (biyoelektrik impedans analizi, BİA) ölçümleri alınmıştır. Vücut komposizyonu ve vücut ağırlığı ise bireylerin en az 4 saat açlık sonrası InBody 230 cihazı (Inbody Co., Ltd., Korea) ile vücut yağ yüzdesi (\%), viseral yağ alanı (karın içi yağlanma) yağsız vücut kütlesi (kg) 
ölçülmüştür. BKİ değerlerine $\left(<24.9 \mathrm{~kg} / \mathrm{m}^{2}\right.$ ve $\geq 25.0$ $\mathrm{kg} / \mathrm{m}^{2}$ ) göre vücut kompozisyonu analiz sonuçları ve Cuzick-Tyrer Modeli ile meme kanseri risk analizi değerlendirilmiştir. Obezite durumu, Dünya Sağlık Örgütü (DSÖ) sınıflamasına göre değerlendirilmiştir (10).

\section{Verilerin İstatistiksel Değerlendirmesi}

Veriler SPSS 22.0 istatistik paket programı (IBM, Armonk, NY) ile değerlendirilmiştir. Tanımlayıcı istatistikler sayı (S), yüzde (\%), ortanca, aritmetik ortalama $(\overline{\mathrm{X}})$ ve standart sapma (SS) ile gösterilmiştir. Grup karşılaştırmalarında "bağımsız gruplarda t-testi” kullanılmış ve $p<0.05$ olması durumunda farkın istatistiksel açıdan önemli olduğu kabul edilmiştir.

\section{BULGULAR}

Katılımcıların ortanca yaşı 35.3 yıldır. Sosyodemografik özellikleri incelendiğinde; \%74.8'inin ortaokul ve altı, \%25.2'sinin lise ve üzeri eğitim düzeyine sahip olduğu saptanmıştır. Kadınların \%58.1'inde ilk menstrüel siklus yaşı $\geq 13$ yıldır. Kadınların \%75.5'i doğum yapmıştır \%96.6'sında ilk doğum yaşı $\leq 30$ yıldır Kadınların \%60.7’si $\geq 12$ ay süreyle bebeğini emzirmiştir. Kadınların \%87.7’sinin henüz menopoza girmediği ve çoğunluğunun (\%83.2) herhangi bir kronik hastalığının olmadığı saptanmıştır (Tablo 1).

Kadınların meme kanseri risk etmenleri ve erken tanı yöntemlerini kullanma durumu Tablo 2'de verilmiştir. Kadınların \%9.7'sinin ailesinde meme kanseri ve \%1.9'unda over kanseri öyküsü bulunmaktadır. Kadınların \%61.9'u fazla kilolu/şişmandır. Kadınların \%39.4'ü sigara içmekte ve \%22.6'sı alkollü içecek tüketmektedir. Kadınların \%32.3’ü düzenli fiziksel aktivite yapmaktadır. Kadınların \%81.4’ü meme kanserinin erken tanı ve tarama yöntemlerinden en az birisini bilmektedir. Bu yöntemleri uygulama ya da başvurma sıklığı ise KKMM, KMM ve mamografi için sırasıyla \%47.7, \%30.3 ve \%31.0'dür. Kadınların büyük çoğunluğu (\%60.2) bu yöntemlerden hiçbirisini uygulamamış/yaptırmamıştır (Tablo 2).
Cuzick-Tyrer modeline göre kadınların meme kanseri riski analizi değerlendirildiğinde; 47 kadının (\%30.3) 10 yıllık meme kanseri riskinin, 53 kadının (\%34.2) ise yaşam boyu meme kanseri riskinin yüksek olduğu bulunmuştur (Tablo 3).

Kadınların BKİye göre vücut kompozisyonu analiz sonuçları Tablo 4'te verilmiştir. Kadınların özellikle vücut yağ yüzdesinin yüksek olduğu görülmüştür. BKI $\geq 25 \mathrm{~kg} / \mathrm{m}^{2}$ olanlarda visseral yağ alanı ortalama $115.89 \pm 32.7$, ortalama vücut yağ kütlesi $27.52 \pm 7.97$ kg olarak ölçülmüştür. Yağsız vücut kütlesi ortalama $11.29 \pm 1.34 \mathrm{~kg}$ olarak saptanmıştır. Abdominal obezite ise BİA ile ölçüm sonuçlarına göre tüm kadınlarda benzer sonuçlarla $(p<0.001)$ anlamlı bulunmuştur (Tablo 4).

Tablo 1. Kadınların sosyo-demografik özellikleri $(n=155)$

\begin{tabular}{|c|c|c|}
\hline Değişkenler & $\mathbf{S}$ & $\%$ \\
\hline \multicolumn{3}{|l|}{ Yaş (yıl) } \\
\hline $20-29$ & 51 & 32.9 \\
\hline $30-39$ & 58 & 37.4 \\
\hline $40-49$ & 35 & 22.6 \\
\hline $50-59$ & 11 & 7.1 \\
\hline \multicolumn{3}{|l|}{ Eğitim durumu } \\
\hline Ortaokul ve altı & 116 & 74.8 \\
\hline Lise ve üstü & 39 & 25.2 \\
\hline \multicolumn{3}{|l|}{ İlk âdet yaşı (yıl) } \\
\hline$\leq 12$ & 65 & 41.9 \\
\hline$\geq 13$ & 90 & 58.1 \\
\hline \multicolumn{3}{|l|}{ Doğum yapma durumu } \\
\hline Doğum yapan & 117 & 75.5 \\
\hline \multicolumn{3}{|c|}{ İlk doğum yaşı (yıl, n=117) } \\
\hline$\leq 30$ & 113 & 96.6 \\
\hline$>30$ & 4 & 3.4 \\
\hline \multicolumn{3}{|c|}{ Toplam emzirme süresi (ay) (n=112) } \\
\hline$<12$ & 44 & 39.3 \\
\hline$\geq 12$ & 68 & 60.7 \\
\hline \multicolumn{3}{|l|}{ Kronik hastalık* } \\
\hline Var & 26 & 16.8 \\
\hline Yok & 129 & 83.2 \\
\hline \multicolumn{3}{|l|}{ Menopoz durumu } \\
\hline Menopozda olmayan & 136 & 87.7 \\
\hline
\end{tabular}


Tablo 2. Kadınların meme kanseri risk etmenleri dağılımı ve erken tanı yöntemlerini bilme ve uygulama durumu

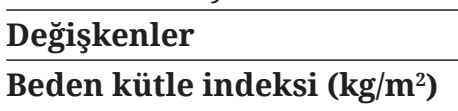

$\leq 24.9$

$59 \quad 38.1$

$\geq 25.0$

$96 \quad 61.9$

Ailede meme kanseri öyküsü

Var

Yok

Ailede over kanseri öyküsü

Var

Yok

Sigara içme durumu

İçmeyen

İçen

Birakan

Alkol kullanma durumu

Kullanmayan

Düzensiz olarak kullanan

Düzenli spor yapma alışkanlığı

Var

Yok

Erken tanı yöntemlerini uygulama:

Kendi kendine meme muayenesi

$\begin{array}{lcc}\text { Evet } & 74 & 47.7 \\ \text { Hayır } & 81 & 52.3 \\ \text { linik meme muayenesi } & & \\ \text { Evet } & 47 & 30.3 \\ \text { Hayır } & 108 & 69.7 \\ \text { Mamografi } & & \\ \text { Evet } & 48 & 31.0 \\ \text { Hayır } & 107 & 69.0\end{array}$

Tablo 3. Kadınların Cuzick-Tyrer modeline göre meme kanseri risk düzeyleri

\begin{tabular}{lcc}
\hline Özellikler & S & \% \\
\hline $\begin{array}{l}\text { Cuzick-Tyrer modeline göre } \mathbf{1 0} \text { yıllık } \\
\text { risk }\end{array}$ & & \\
$\quad$ Düşük & 108 & 69.7 \\
$\quad$ Yüksek & 47 & 30.3 \\
Cuzick-Tyrer modeline göre yaşam & & \\
boyu risk & & \\
$\quad$ Düşük & 102 & 65.8 \\
$\quad$ Yüksek & 53 & 34.2 \\
\hline
\end{tabular}

Kadınların meme kanseri konusundaki bilgi düzeyleri, beslenme alışkanlıkları, riskli besin tüketim özellikleri ve vitamin kullanma durumlarının dağılımı Tablo 5’te gösterilmiştir. "Son bir yıl içerisinde beslenme alışkanlığınızda değişiklik oldu mu?” sorusuna katılımcıların \%27.1'i “evet, sağllklı yönde değişti” yanıtını vermiştir. Katılımcıların \%89.7'si herhangi bir vitamin-mineral takviyesi kullanmadığını belirtmiştir. Kadınların meme kanserinden korunmada yararlı olabilecek besinleri tüketim sıklığı değerlendirildiğinde ise; haftada 1-2 gün balık, kırmızı et ve kurubaklagil tüketenlerin oranları sirasılya \%65.8, \%52.3 ve \%81.3 iken, sebze ve meyveleri her gün tüketenlerin sıklığı \%95.5 ve \%89.0 olarak saptanmıştır. Bunun yanısıra her gün tam tahıllı ekmek tüketenlerin oranı (\%60), beyaz ekmek tüketenlere (\%49) göre daha yüksek bulunmuştur. Her gün zeytinyağı tüketim sıklığı yüksek bir oranda (\%98.7) görülürken, hiç margarin tüketmediğini belirten katılımcıların oranı \%60.6 olarak bulunmuştur. Şekerli gıdaları haftada 1-2 gün tüketenlerin sıklığı \%49.7’dir. Ayrıca kadınların \%51.3'ü meme kanseri ile beslenme ve obezite arasında bir ilişki olduğunu belirtmiştir (Tablo 5).

\section{TARTIŞMA}

Meme kanseri dünyanın farklı bölgelerinde çok farklı sıklıkta görülmekte olup, Asya ve Afrika'da 100.000'de 29-36 iken, Kuzey Amerika ve Batı Avrupa'da 100.000'de 91-96 arası sıklıkta görülmektedir (11). Bu farklar üreme ile ilgili etkenler (geç yaşta ilk gebelik, gebelik sayısının az olması, emzirme süresinin kısa olması veya hiç emzirmemek, menstruasyon dönemine erken girmek, menopoz dönemine geç girmek) ve yaşam tarzı risk etkenlerinin (şişmanlık, hareketsizlik, alkollü içecek tüketimi, batı tarzı diyet ve hormon kullanımı) farklı olmasindan kaynaklanmaktadır. Meme kanseri erken tanı ile tedavi edilebilmektedir $(6,11)$.

Meme kanserinin erken evrede teşhis edilmesi için DSÖ, uluslararası otoriteler ve kanser enstitülerinin 
Tablo 4. Beden kütle indeksi sınıflamasına göre vücut kompozisyon analiz sonuçlarının karşılaştırılması (n=155)

\begin{tabular}{|c|c|c|c|c|c|}
\hline & $\begin{array}{c}\text { BKI } \\
\left(\mathrm{kg} / \mathrm{m}^{2}\right)\end{array}$ & $\mathbf{S}$ & $\overline{\mathrm{X}}$ & SS & $\boldsymbol{P}$ \\
\hline \multirow{2}{*}{ Viseral yağ alanı } & $<24.9$ & 56 & 60.41 & 20.01 & \multirow{2}{*}{0.001} \\
\hline & $\geq 25.0$ & 99 & 115.89 & 32.07 & \\
\hline \multirow{2}{*}{ Minimum vücut hücre dokusu (kg) } & $<24.9$ & 56 & 24.39 & 1.76 & \multirow{2}{*}{0.040} \\
\hline & $\geq 25.0$ & 99 & 23.79 & 1.69 & \\
\hline \multirow{2}{*}{ Maksimum vücut hücre dokusu (kg) } & $<24.9$ & 56 & 29.80 & 2.17 & \multirow{2}{*}{0.040} \\
\hline & $\geq 25.0$ & 99 & 29.06 & 2.08 & \\
\hline \multirow{2}{*}{ Vücut yağ kütlesi (kg) } & $<24.9$ & 56 & 20.24 & 10.2 & \multirow{2}{*}{0.001} \\
\hline & $\geq 25.0$ & 99 & 27.52 & 7.97 & \\
\hline \multirow{2}{*}{ Vücut yağ oranı (\%) } & $<24.9$ & 56 & 31,86 & 8.80 & \multirow{2}{*}{0.001} \\
\hline & $\geq 25.0$ & 99 & 39.06 & 7.29 & \\
\hline \multirow{2}{*}{ Abdominal obezite } & $<24.9$ & 56 & 0.87 & 0.06 & \multirow{2}{*}{0.001} \\
\hline & $\geq 25.0$ & 99 & 0.93 & 0.06 & \\
\hline \multirow{2}{*}{ Yağsız vücut kütlesi (kg) } & $<24.9$ & 56 & 10.45 & 1.37 & \multirow{2}{*}{0.001} \\
\hline & $\geq 25.0$ & 99 & 11.29 & 1.34 & \\
\hline
\end{tabular}

Tablo 5. Kadınların beslenme alışkanlıkları ve besin tüketim sıklığı (n=155)

\begin{tabular}{|c|c|c|c|}
\hline \multicolumn{2}{|l|}{ Beslenme alışkanlıkları ve besin tüketim sıklığı } & \multirow{2}{*}{$\begin{array}{c}\mathbf{S} \\
139\end{array}$} & \multirow{2}{*}{$\begin{array}{c}\mathbf{\%} \\
89.7\end{array}$} \\
\hline Vitamin ve mineral desteği alma durumu & Hayır & & \\
\hline & Evet & 16 & 10.3 \\
\hline \multirow[t]{2}{*}{ Son bir yılda beslenme düzeninin değişme durumu } & Evet sağlıklı yönde & 42 & 27.1 \\
\hline & Hayır aynı & 104 & 67.1 \\
\hline \multirow[t]{4}{*}{ Kırmızı et tüketim sıklığı } & Günde bir & 12 & 7.7 \\
\hline & Haftada 1-2 & 81 & 52.3 \\
\hline & Ayda bir & 50 & 32.3 \\
\hline & Hiç & 12 & 7.7 \\
\hline \multirow[t]{4}{*}{ Beyaz et tüketim sıklığı } & Günde bir & 12 & 7.7 \\
\hline & Haftada 1-2 & 124 & 80.0 \\
\hline & Ayda bir & 16 & 10.3 \\
\hline & Hiç & 3 & 1.9 \\
\hline \multirow[t]{4}{*}{ Balık tüketim sıklığı } & Günde bir & 1 & 0.6 \\
\hline & Haftada 1-2 & 102 & 65.8 \\
\hline & Ayda bir & 35 & 22.6 \\
\hline & Hiç & 17 & 11.0 \\
\hline \multirow[t]{4}{*}{ İşlenmiş et tüketim sıklığı } & Günde bir & 4 & 2.6 \\
\hline & Haftada 1-2 & 28 & 18.1 \\
\hline & Ayda bir & 33 & 21.3 \\
\hline & Hiç & 90 & 58.1 \\
\hline \multirow[t]{4}{*}{ Yumurta tüketim sıklığı } & Günde bir & 36 & 23.2 \\
\hline & Haftada 1-2 & 109 & 70.3 \\
\hline & Ayda bir & 4 & 2.6 \\
\hline & Hiç & 6 & 3.9 \\
\hline \multirow[t]{4}{*}{ Kurubaklagil tüketim sıklığı } & Günde bir & 9 & 5.8 \\
\hline & Haftada 1-2 & 126 & 81.3 \\
\hline & Ayda bir & 17 & 11.0 \\
\hline & Hiç & 3 & 1.9 \\
\hline
\end{tabular}


Tablo 5. Devamı Kadınların beslenme alışkanlıkları ve besin tüketim sıklığı (n=155)

\begin{tabular}{|c|c|c|c|}
\hline Beslenme alışkanlıkları ve besiı & & $\mathbf{S}$ & $\%$ \\
\hline Sebze tüketim sıklığı & Günde bir & 148 & 95.5 \\
\hline & Haftada 1-2 & 7 & 4.5 \\
\hline & Ayda bir & - & - \\
\hline & Hiç & - & - \\
\hline Meyve tüketim sıklığı & Günde bir & 138 & 89.0 \\
\hline & Haftada 1-2 & 13 & 8.4 \\
\hline & Ayda bir & 3 & 1.9 \\
\hline & Hiç & 1 & 0.6 \\
\hline Tam tahıllı ekmek tüketim sıklığı & Günde bir & 93 & 60.0 \\
\hline & Haftada $1-2$ & 71.8 & 11.6 \\
\hline & Ayda bir & 7 & 4.5 \\
\hline & Hiç & 3.7 & 23.9 \\
\hline Beyaz ekmek tüketim sıklığı & Günde bir & 76 & 49.0 \\
\hline & Haftada 1-2 & 18 & 11.6 \\
\hline & Ayda bir & 20 & 12.9 \\
\hline & Hiç & 41 & 26.5 \\
\hline Hamur-işi besin tüketim sıklığı & Günde bir & 37 & 23.9 \\
\hline & Haftada 1-2 & 89 & 57.4 \\
\hline & Ayda bir & 19 & 12.3 \\
\hline & Hiç & 10 & 6.5 \\
\hline Margarin tüketim sıklığı & Günde bir & 19 & 12.3 \\
\hline & Haftada 1-2 & 23 & 14.8 \\
\hline & Ayda bir & 19 & 12.3 \\
\hline & Hiç & 94 & 60.6 \\
\hline Zeytinyağı tüketim sıklığı & Günde bir & 153 & 98.7 \\
\hline & Haftada 1-2 & 2 & 1.3 \\
\hline & Ayda bir & - & - \\
\hline & Hiç & - & - \\
\hline Şekerli gıdalar tüketim sıklığı & Günde bir & 33 & 21.3 \\
\hline & Haftada 1-2 & 77 & 49.7 \\
\hline & Ayda bir & 25 & 16.1 \\
\hline & Hiç & 20 & 12.9 \\
\hline
\end{tabular}

ortak görüş olarak; KMM için 20 yaşından sonra 2 yılda bir, 40 yaşından sonra yllda bir kez meme muayenesi yaptırılmasını ve düzenli olarak mamografi çektirilmesini önermektedir $(6,10,12,13)$.

Bu çalışmaya katılan kadınların \%81.4’ünün meme kanserinin erken tanı ve tarama yöntemlerinden en az birini bildiği saptanmıştır. Bu oranın yüksek olmasında, kadınların hastanede çalışıyor olmaları, dolayısıyla sağlık çalışanlarından erken tanı ve tarama yöntemleri hakkında bilgi edinmeleri etkili olabilir. KKMM meme kanserinin erken tanısinda basit, ekonomik ve kadının yaşadığı ortamda kolayca uygulayabileceği bir yöntemdir. Ancak çalışmaya katılan kadınların \%52.3’ü hiç KKMM yapmadığını belirtirken \%30.3’ü KMM ve \%31'i mamografi yaptırmıştır. Kadınların sadece \%3.5’i ise kendisine biyopsi önerildiğini belirtmiştir. $\mathrm{Bu}$ oranlar bu kadınların risk grubunda olduğunu gösterebilir.

Meme kanserinin oluşması sürecinde yaşam şekli ve beslenme durumunun etkileri günümüzde çok araştırılan bir konudur. Kohort çalışmalar genellikle fazla kilolu, şişman olmanın ve yetişkinlikte vücut ağırlığının artmasının menopoz sonrası meme kanseri riski ile ilişkili olduğunu ileri sürmektedir 
(14). Yetişkinlikte vücut ağırlığı $20 \mathrm{~kg}$ veya daha fazla artan kadınların meme kanseri riskinin iki katına çıkabileceği belirtilmektedir (14,15). Buna karşın yetişkinlikte vücut ağırlığının az miktarda (\%5-10) azalması meme kanseri riskini azaltmaktadır (16). Iowa Kadın Sağlığı Çalışmasında (34.000 kadını kapsamıştır), menopoz döneminden önce veya sonra kadınların vücut ağırlığında en az \%5 azalmanın vücut ağırlığının artmasına kıyasla meme kanseri riskini \%25-40 oranında azalttığı saptanmıştır (17).

Benzer olarak Eliassen et al. (18) da Hemşirelerin Sağlık Çalışması'nda; vücut ağırlığı değişmeyen kadınlarla karşılaştırıldığında, vücut ağırlığı \%10 azalan kadınlarda meme kanseri görülme riskinin \%50 azaldığını bildirmiştir. Özellikle östrojen reseptörü (ER) pozitif ve ER negatif olan meme kanseri gelişme riskiyle şişmanlık ilişkilendirilmekte, aynı zamanda menopoz sonrası ailesinde meme kanseri olan ve olmayan kadınlar arasında da ER ile şişmanlık ilişkisinin olduğu belirtilmektedir (14,15).

$\mathrm{Bu}$ çalışmada da BKI $\geq 25 \mathrm{~kg} / \mathrm{m}^{2}$ olan kadınlarda (\%63.9) vücut ağırlığının yüksek olması meme kanseri riskinin önemli bir nedeni olarak düşünülmektedir. Bu çalışmada meme kanseri risk değerlendirilmesinde kullanılan Cuzick-Tyrer modeli Amerika Birleşik Devletleri'nde kadınlarda sıklıkla kullanılan ve kullanılması önerilen bir tarama yöntemi olarak son yıllarda dikkat çekmektedir $(5,13)$. Cuzick-Tyrer analiz modelinde de kullanılan BKİnin, ayrıca kadınlarda BİA ile ölçülen vücut yağ kütlesi ve özellikle viseral yağlanma değerlerinin BKİ $\geq 25 \mathrm{~kg} / \mathrm{m}^{2}$ olan kadınlarda fazla olduğu görülmüş, istatistiksel olarak önemli bulunmuştur. $(p<0.001)$ Aynı şekilde BİA ile alınan abdominal obezite değerleri de anlamlı olarak $(p<0.001)$ bu bulguları desteklemektedir. Vücudun yağ kütlesinin artması ile BKİnin artması arasında doğru orantılı ilişki görülebilir. CuzickTyrer analiz modelinde gelecekteki araştırmalarda yeni bir parametre olarak düşünülebilir. Bu alanda çalışmaların sayısının artması önerilebilir.

Yapılan bu çalışmada Cuzick-Tyrer modeline göre kadınların \%34.7’sinin yaşam boyu meme kanseri riski olduğu gösterilmiştir. Kadınların \%87.7’nin henüz menopoz dönemine girmediği göz önüne alınırsa kadınların daha sonraki yıllarda vücut ağırlığının ve vücut yağ kütlelerinin artması nedeniyle meme kanseri riskinin de artacağı öngörülmektedir.

Kadınların vücut yağ kütlesindeki artış ile meme kanser riski ilişkisi diğer araştırmalar ile karşılaştırıldığında; kohort çalışmalarda, menopoz dönemi sonrası kadınlarda vücut ağırlığının ve alkollü içecek tüketiminin azalmasının meme kanseri riskini \%16-60 oranında azalttığı bildirilmiştir (11,14,19,20). Buna karşılık, menopoz öncesi ve sonrası kadınlardan oluşan bir kohort çalışmada ise; diğer yaşam tarzı faktörlerinden çok diyetlerinde kepekli ürünleri artıran, et ve alkol tüketimini azaltmış olan kadınlarda \%31 daha düşük meme kanseri oranı gösterilmiştir (15). Yapılan bu çalışmada ise besin tüketim sıklığına göre kadınların balık, kurubaklagil ve tam tahıllı ekmek tüketiminin daha fazla olduğu görülmektedir.

Dünya Kanser Araştırma Fonu'nun Kanser Önleme kılavuzlarında, meyve, sebze ve tam tahillı, fazla posalı besinlerin tüketimini öneren diyet modellerinin kanser riskini azalttığı belirtilmektedir (13,21-23). Bu çalışmada her gün sebze ve meyve tüketme sıklığı oranının çok yüksek olduğu görülmektedir. $\mathrm{Bu}$ ise Ege bölgesinde ki beslenme alışkanlıkları ile ilişkili olabilir. Türkiye Beslenme ve Sağlık Araştırmasında (TBSA-2010) kadınların eğitim düzeyleri arttıkça sebze ve meyve tüketim sıklığının arttığı saptanmıştır (24).

Son sistematik incelemelere göre, günlük posa alımının 10gm artırılmasının kanser riskini \%5 azalttığı belirtilmiştir (21,23). Posa, bağırsaktaki östrojen ve androjenlerin yeniden emilimini ve dolayısıyla dolaşımdaki düzeylerini azaltarak kanser oluşması riskini azaltabilir $(23,25,26)$.

Kadınların özellikle, posadan zengin olan sebze ve meyve tam tahıllı ürünler ve kurubaklagil tüketim sıklığının fazla olması bu koruyuculuk özelliğini farklı mekanzimalar ile sağlayabileceği öngörülebilir.

Son yıllarda omega-3 yağ asitleri, eikosapentaenoik asit (EPA) ve dokosaheksaenoik asit (DHA) meme 
kanseri riskinde azalma ile ilişkili bulunmuştur. Her hafta tüketilen $0.7 \mathrm{~g}$ omega-3 yağ asidinin riski \%5 oranında azalttığı, haftada iki porsiyon yağlı balık ile sağlanan 3.5 g n-3 yağ asidi ise potansiyel olarak \%25 risk azaltımı sağladığı gösterilmiştir $(11,15)$. Çalışmada kadınların balık tüketim sıklığının haftada 1-2 kez olarak \%65.8 oranında görülmesi gelecekte meme kanseri risk azalmasında yararlı bir etkisinin olabileceğini düşündürmektedir.

Zeytinyağının literatürde özellikle moleküler çalışmalar ile meme kanserindeki koruyucu etkisi içerdiği oleik asit, oleuropein, tirozol gibi moleküller ile gösterilmiştir. Meme kanseri olan kadınlarda \%25-30 pozitif olan Her-2/neu genini baskılayıcı etki gösterdiği ve inflamasyonu azalttığı belirlenmiştir $(15,19)$. Çalışmada bu amaçla zeytinyağı tüketim sıklığı sorgulandığında, hergün tüketenlerin oranı \%98.7 gibi bir değer ile çok dikkat çekmiştir. Kadınların zeytinyağı tüketiminde, Ege bölgesi beslenme alışkanlıklarının etkisi, ekonomik açıdan üretici gruplardan olması ve zeytinyağının sağlığa yararlı etkileri konusundaki önerilerden etkilenmiş olmaları rol oynayabilir.

Meme kanseri vakalarının \%9.0'unun yetersiz fiziksel aktivite yapmasının olumsuz etkili olduğu belirtilmektedir (27). Fiziksel aktivitenin potansiyel anti-kanser etkileri; endojen seks hormonlarının düzeyinde, insülin direncinde ve kronik inflamasyonda azalmayı sağlaması olarak belirtilmektedir (15,22,28). Özellikle ergenlik ve erken yetişkinlik döneminde fiziksel aktivite yapılmasının kanser riskini azalttığıda gösterilmiştir (22). Ancak bu çalışmaya katılan kadınların ise sadece üçte biri düzenli fiziksel aktivite yaptığını belirtmiştir.

Meme kanseri risk etmenlerinden birisi olan sigara içme alışkanlığı konusunda yapılan çalışmalar; ailesinde kanser olan BRCA1 ve BRCA2 taşıyıcılarında kanser riskinin vücut ağırlığı artışı ve sigara içme ile arttığına dair kesin kanitlar ortaya koymuştur $(29,30,31)$. Ancak bu ilişkinin varlığını destekleyecek büyük ölçekli çalışmaların yapılması gerekmektedir. $\mathrm{Bu}$ çalışmada ki kadınların ise \%51.6’sının sigara içmediği bulunmuştur. Kadınların hastane ortamında çalışıyor olmalarının azaltıcı etkenlerden birisi olabileceği düşünülmüştür.

Sonuç olarak; başarılı yaşam biçimi değişikliklerinin meme kanseri vakalarının \%25-30'unu önleyebileceği belirtilmektedir (31). Menopoz öncesi dönemde gelişen \%20-25 meme kanseri vakasının çocukluk, ergenlik döneminde özellikle meme hücreleri farklılaşmadan ve karsinojeneze duyarlı hale gelmeden önce menarş ve ilk gebelik arasındaki dönemde başlayabileceği görüşü oluşmaktadır (31,32). Kanser Enstitüleri ve DSÖ’nün ortak önerisi; kadınların 20 yaşından sonra 2 yılda bir KMM, 40 yaşından sonra yılda bir kez KMM yaptırması ve düzenli olarak mamografi çektirilmesi şeklinde olmaktadır $(10,11)$.Ülkemizde artan şişmanlık nedeniyle 20 yaş sonrası erişkin döneme geçişte ve menopoz döneminde kadınlar için dengeli bir vücut ağırlığı kontrolü ve fiziksel aktivitenin artırılması ile insulin direncinin azaltılması önerilmektedir $(6,8,12)$.

$\mathrm{Bu}$ çalışmada elde edilen bulgular doğrultusunda hastanede çalışan kadınların meme kanseri konusunda farkındalığının olmasına karşın, erken tanı yöntemlerini düzenli uygulamadığı, meme kanseri bilgisinin beslenme alışkanlıkları ve özellikle vücut ağırlığı kontrolünde etkilerinin olmadığı saptanmıştır. Özellikle kadınlara 20 yaşından itibaren uygulanması önerilen KKMM yönteminin yaygınlaştırılması konusunda çalışmalar artırılabilir. Ailesinde kanser öyküsü ve BKİ'i $\geq 25 \mathrm{~kg} / \mathrm{m}^{2}$ olan kadınlara koruyucu sağlık hizmetlerinde CuzickTyrer modeli risk analizinin uygulanması önerilebilir. Ayrıca BİA ile yapılan değerlendirmelerde özellikle vücut yağ kütlesi artan, abdominal obezite riski olan kadınlara ayda bir kez KKMM, iki yılda bir KMM ile kontrolü yapılması erken tanı için yararlı olacaktır.

Meme kanserinden korunmada; genç erişkinlik ve menopoz dönemlerinde olan kadınlara vücut ağırlığının aşırı artışı, visseral yağlanmanın artması, kanser riskini azaltan besinlerin yetersiz tüketilmesi, hareketsiz yaşamın ve sigara içmenin olumsuz etkileri hakkında koruyucu sağlık hizmetlerinin verilmesi çok yararlı olacaktır. Ayrıca bu konuda tüm sağlık 
kuruluşlarında çalışan bireyler için sürekli eğitim programları düzenlenebilir.

Çıkar çatışması - Conflict of interest: Yazarlar çıkar çatışması olmadığını beyan ederler. - The authors declare that they have no conflict of interest.

Destekleyen kuruluş: Bu araştırma Dokuz Eylül Üniversitesi Rektörlüğü Bilimsel Araştırma Projeleri (BAP) Destekleme Fonu tarafindan (2009.KB.SAĞ.093) desteklenmiştir.

\section{KAYNAKLAR}

1. Cancer Stat Facts: Female Breast Cancer SEER. Available at: https://seer.cancer.gov/statfacts/html/breast Accessed 27 August 27, 2019.

2. World Health Organization. Cancer Prevention. Available at: http://www.who.int/cancer/prevention/en Accessed September 23, 2019.

3. American Cancer Society. Breast Cancer: Can Breast Cancer Be Found Early? Available at: http://www.cancer. org/cancer/breastcancer/detailedguide/breast-cancerdetection?rnav=cri Accessed December 30, 2019.

4. Benson JR, Jatoi İ, Keisch M, Esteva FJ, Makris A, Jordan VC. Early breast cancer. Lancet. 2009;373:1463-79.

5. Boughey JC, Hartmann LC, Anderson SS, Degnim AC, Vierkant RA, Reynolds CA, et al. Evaluation of the TyrerCuzick (International Breast Cancer Intervention Study) Model for breast cancer risk prediction in women with atypical hyperplasia. J Clin Oncol. 2010;28(22):3591-6.

6. World Cancer Research Foundation, Diet, nutrition, physical activity and breast cancer. Continous update project. Expert Report. No:50, 2018.

7. Debbie Saslow, Judy Hannan, Janet Osuch, Marianne H. Alciati, et al. Clinical breast examination: practical recommendations for optimizing performance and reporting. CA Cancer J Clin. 2004;54;327-44.

8. Sağlık Bakanlığı Türkiye Halk Sağlığı Kurumu. Kanser Taramaları. Erişim: https://hsgm.saglik.gov.tr/tr/kansertaramalari Erişim Tarihi: 30 Aralık 2019.

9. Friebel TM, Domchek SM, Rebbeck TR. Modifiers of cancer risk in BRCA1 and BRCA2 mutation carriers: systematic review and meta- analysis. J Natl Cancer Inst. 2014;106(6):dju091.

10. World Health Organization. Diet, nutrition and the prevention of chronic diseases: Report of a Joint WHO/ FAO Expert Consultation, Public Health Nutrition, Vol 7, No. 1(A), Supplement 1001, February 2004.

11. Kushi LH, Doyle C, McCullough M, Rock CL, DemarkWahnefried W, Bandera EV, et al. American Cancer Society Guidelines on nutrition and physical activity for cancer prevention: reducing the risk of cancer with healthy food choices and physical activity. CA Cancer J Clin. 2012;62(1):30-67.

12. Özmen V. In: Özmen V eds. Breast Cancer in Turkey. An analysis of 20.000 patients. 1st ed. İstanbul: Cinius Yayınları; 2017. p.60

13. Brentnall AR, Cuzick J, Buist DSM, Bowles EJA. Longterm accuracy of breast cancer risk assessment combining classic risk factors and breast density JAMA Oncol. 2018;4(9):e180174.

14. Vrieling A, Buck K, Kaaks R, Chang-Claude J. Adult weight gain in relation to breast cancer risk by estrogen and progesterone receptor status: a meta- analysis. Breast Cancer Res Treat. 2010;123:641-9.

15. McKenzie F, Ferrari P, Freisling H, Chajès V, Rinaldi $\mathrm{S}$, de Batlle J, et al. Healthy lifestyle and risk of breast cancer among postmenopausal women in the European Prospective Investigation into Cancer and Nutrition cohort study. Int J Cancer. 2015;136(11):2640-8.

16. Catsburg C, Miller AB, Rohan TE. Adherence to cancer prevention guidelines and risk of breast cancer. Int J Cancer. 2014;135(10):2444-52.

17. Van den Brandt PA, Spiegelman D, Yaun SS, Adami HO, Beeson L, Folsom AR, et al. Pooled analysis of prospective cohort studies on height, weight, and breast cancer risk. Am J Epidemiol. 2000;152:514-27.

18. Eliassen AH, Colditz GA, Rosner B, Hankinson SE. Adult weight change and risk of postmenopausal breast cancer. JAMA. 2006;296:193-201.

19. Hastert TA, Beresford SA, Patterson RE, Patterson RE, Kristal AR, White E. Adherence to WCRF/ AICR cancer prevention recommendations and risk of postmenopausal breast cancer. Cancer Epidemiol Biomarkers Prev. 2013;22:1498-508.

20. Scoccianti C, Lauby-Secretan B, Bello PY, Romieu I. Female breast cancer and alcohol consumption: a review of the literature. Am J Prev Med .2014;46(3 Suppl 1):16-25.

21. Aune D, Chan DS, Greenwood DC, Vieira AR, Rosenblatt DA, Vieira R, et al. Fruits and vegetables: updating the epidemiologic evidence for the WCRF/AICR lifestyle recommendations for cancer prevention. Cancer Treat Res. 2014;159:35-50.

22. Neilson HK, Conroy SM, Friedenreich CM. The influence of energetic factors on biomarkers of postmenopausal breast cancer risk. Curr Nutr Rep. 2014;3:22-34.

23. Kerr J, Anderson C, Lippman SM. Physical activity, sedentary behaviour, diet, and cancer: an update and emerging new evidence. Lancet Oncol. 2017;18(8):45771.

24. Türkiye Beslenme ve Sağllk Araştırması 2010. Beslenme durumu ve alışkanlıklarının değerlendirilmesi 
sonuç raporu. Available at: www.sagem.gov.tr/TBSA_ Beslenme_Yayini.pdf. Erişim tarihi 20 Aralık 2019.

25. Rock CL, Doyle C, Demark-Wahnefried W, Meyerhardt J, Courneya KS, Schwartz AL, et al. Nutrition and physical activity guidelines for cancer survivors. CA Cancer J Clin. 2012;62(4):243-74.

26. Vieira AR, Rosenblatt DA, Vieira R, Norat T. Dietary fiber and breast cancer risk: a systematic review and meta-analysis of prospective studies. Ann Oncol. 2012;23:1394-402.

27. Leitzmann M, Powers H, Anderson AS, Scoccianti C, Berrino F, Boutron-Ruault MC, et al. European Code against Cancer 4th Edition: Physical activity and cancer. Cancer Epidemiol. 2015;39(Suppl 1):46-55.

28. Wu Y, Zhang D, Kang S. Physical activity and risk of breast cancer: a meta-analysis of prospective studies. Breast Cancer Res Treat. 2013;137:869-82.
29. Milne RL, Antoniou A. Modifiers of breast and ovarian cancer risks for BRCA1 and BRCA2 mutation carriers. Endocr Relat Cancer. 2016;23(10):T69-84.

30. Pettapiece-Phillips R, Narod SA, Kotsopoulos J. The role of body size and physical activity on the risk of breast cancer in BRCA mutation carriers. Cancer Causes Control. 2015;26:333-44.

31. Cloud AJ, Thai A, Liao Y, Terry MB. The impact of cancer prevention guide-line adherence on overall mortality in a high-risk cohort of women from the New York site of the Breast Cancer Family Registry. Breast Cancer Res Treat. 2015;149:537-46.

32. Barrdahl M, Rudolph A, Hopper JL, Southey MC, Broeks A, Fasching PA, et al. Gene-environment interactions involving functional variants: Results from the Breast Cancer Association Consortium. Int J Cancer. 2017;141(9):1830-40. 